\title{
Raising Introspective Awareness in Resisting Colonizing Ideologies: Coetzee's Waiting for the Barbarians
}

\author{
Sameer M. Al-Shraah*
}

Department of English, Al Albayt University, Jordan

Corresponding Author: Sameer M. Al-Shraah, E-mail: ssmmrr33@yahoo.com

\section{ARTICLE INFO}

Article history

Received: June 20, 2017

Accepted: September 27, 2017

Published: October 31, 2017

Volume: 8 Issue: 5

Advance access: October 2017

Conflicts of interest: None

Funding: None

Key words:

Colonization,

Dehumanization,

Self-introspection,

Empire

\begin{abstract}
Deconstructing colonization and the colonizing discourse is a long and continuing process. Many intellectuals participated, and still participate, in this noble mission. However, "Waiting for the Barbarians" is a literary work that resists the colonial ideology through raising the colonizer's, and consequently the reader's, awareness of the pervasive ideology of dehumanization; it is this ideology that makes possible the severe torture of the prisoners without the torturers' feeling or awareness of their criminal deeds. This ideology of dehumanization and the struggle against its domination is manifested by the character of the protagonist who, as a representative of the colonizer, experiences a gradual process of confusion, introspection, and remorse that enables the reader to experience closely, rather than merely witness from a distance, an exemplary process of self-questioning. This theme of self-questioning is one of the main themes of Coetzee's Waiting for the Barbarians. The novel creates in us an ability to question the different ideologies that enslaved us unconsciously, especially at our modern time when It seems that we became so obsessed with materialism and our existential needs that risking one's physical safety or financial security to stand up for one's principles will never be an issue for most people, especially those living in what was known as colonizing countries or, in modern terminology, the developed or first world. Thus, the aim of this paper is to investigate how the novel creates in its reader a revival of a moral and ultimately political sensibility that is usually inhibited by the ideology of dehumanization.
\end{abstract}

Coetzee's Waiting for the Barbarians was written during the years of apartheid in South Africa. It was first published in 1980. The links between Coetzee's fictional "Empire" and the practices of South Africa's Nationalist government are clear. The novel was written in 1979, at a time when torture in South Africa had suddenly become the focus of international attention. This period was characterized by apartheid and imprisonment of thousands of South Africans who protested against the white domination and racial legislation of the Nationalist government. The only interest of the racial government was to protect the superiority of the white Europeans while enhancing the inferiority of the black and the colored who form the majority of the population.

Deconstructing colonization and the colonizing discourse is a long and continuing process. Many intellectuals participated, and still participate, in this noble mission. However, postcolonial researches usually focus on the colonized rather than the colonizer. Critics often focus on deconstructing the colonizer's ideology from the colonized point of view. Literary critics rarely expose the dehumanizing ideology of colonization through analyzing some of the colonialist characters who are able to reach an anti-colonial awareness through a gradual process of critical self-questioning. This process of self-questioning and introspective awareness happens not only amongst colonized societies, but also within the colonialist people themselves. Thus, the aim of this paper is to investigate how the novel creates in its reader a revival of a moral and ultimately a political, anti-colonial sensibility that is usually inhibited by the ideology of dehumanization. Waiting for the Barbarians is a literary work that resists the colonial ideology through making the colonizer and the reader aware of the pervasive ideology of dehumanization; it is this ideology that makes possible the severe torture of the prisoners without the tortures' feeling or awareness of their criminal deeds. This ideology of dehumanization and the struggle against its domination is manifested by the character of the protagonist who, as a representation of the colonizer, experiences a gradual process of confusion, introspection, and remorse that enables the reader to experience closely, rather than merely witness from a distance, an exemplary process of self-questioning.

This theme of self-questioning is one of the main themes of Coetzee's Waiting for the Barbarians. The novel creates in us an ability to question the different ideologies that enslaved us unconsciously, especially at our modern time when It seems that we became so obsessed with materialism and our existential needs that risking one's physical safety or financial security to stand up for one's principles will never 
be an issue for most people, especially those living in what was known as colonizing countries or, in modern terminology, the developed or first world. Modern civilized people of our time became mainly concerned with how to acquire a car, Cellular phones, Cocoa Puffs, Pentium IV PC's, DVD players: these are the luxury items of wealthy, satisfied countries. In the developed countries, the primary concern of many individuals is whether or not they will be able to acquire PlayStations for their child's birthday or having to put one's dog or cat to sleep. However, there is nothing wrong with that as long as we are not enslaved to the different ideologies around us. One of these ideologies is the fear of being threatened by the 'other' which the colonizing states keep its people haunted with. This fear justifies the cruel actions taken by these states against the colonized. Nothing would stop these dehumanized actions of the colonizing states than the questioning conscience of its own people. Coetzee makes the place and the time of the novel unknown to us, although it may took place somewhere on the earth, to remind us that the themes of the novels are universal and could happen at any time in any place.

Through his journey of self-questioning, the magistrate becomes aware of many facts: that the Empire he works for gains its power and the support of its subjects from the idea that it is threatened by the barbarians, that the source of fears from the 'barbarians' is the false rumors spread by those who control the Empire and that those fears are unjustifiable, that we, as humans, share the same existential needs that should unify us instead of dividing us into fighting nations, that it is the false ideology of the Empire that makes its subjects torture the poor 'barbarians' without getting affected emotionally by what they see of their suffering as humans.

Before the coming of Colonel Joll and the soldiers from the capital, which represents the Empire headquarter, the magistrate lived a life with the false belief that he is serving a civilized state with his civilized behaviors. He thought that his actions and behaviors are supported by the rule of the law that would secure justice against the brutalities and cruelties of both the barbarians and the Empire. When he reflects back on these days when he served in the courtroom, he remembered what he said to the man who tried to desert from the army to see his mother: "we cannot just do as we wish; we are all subject to the law, which is greater than any of us" (Coetzee 138). However, after he sees that the Third Bureau and its agents, Colonel Joll and Warrant Officer Mandel, embody worst kind of barbarities of the Empire's leadership, the magistrate begins to resist their methods which include physical and psychological torture, insisting that these methods lie outside the law. But after he becomes their prisoner, he understands that even the law will be manipulated by the Third Bureau to provide them with more power in torturing or colonizing the other: "They will use the law against me as far as it serves them, then they will turn to other methods. That is the Bureau way. To people who do not operate under statute, legal process is simply one instrument among others" (84). In spite of this, the magistrate insists on pursuing his mission in teaching the Third Bureau's agents the importance of the autonomy of the law and to distinguish between civilized and barbaric behaviors. Although he knows that his efforts will not succeed, yet he says:

Let it at the very least said, if it ever come to be said, if there is ever anyone in some remote future interested to know the way we live, that is in this farthest outpost of the Empire of light there existed one man who in his heart was not a barbarian (104).

This refers to the magistrate's awareness that barbarism is the product of the civilized Empire and has nothing to do with the real barbarians. He realized that the assumption that the Empire is civilized and the barbarians are less than humans and deserve to be treated like animals is wrong. Dennis Walder referred to what Las Cases "wrote to reverse the stereotyping assumption of the colonizers that the indigenous peoples were less than themselves, indeed less than human, and could be therefore maltreated with impunity"(1081). Walder explains that Las Case's suggestion was that:

The conquistadores, far from being the Christians heroes of ballad and romance who had defeated the 'Moorish barbarians', were themselves unchristian and barbaric in their relation to the American Indians, whom he characterizes in terms of innocence and purity (1081).

Like Las Case, by defending the indigenous peoples and recording a testimony against the colonizer, the magistrate is doing a noble mission which is important "not only as a record of a bolt on European civilization in its expansive phase, but also as... [a] succeeding attempt to speak out on behalf of those who could not, because they had been murdered, silenced, or simply ignored"(1081).

Before the coming of the soldiers and their leaders, Colonel Joll and Warrant Officer Mandel, the relationship between the magistrate and the barbarians is peaceful. The magistrate seems aware that the barbarians are simple people who are not corrupted by the modern ideologies of the Empire:

It used to be that groups of nomads would visit the settlement in winter to pitch their tents outside the walls and engage in barter, exchanging wool, skins, felts and leatherwork for cotton goods, tea, sugar, beans, flour. We prize barbarian leatherwork, particularly the sturdy boots they sew (Coetzee 38).

One of these ideologies is commodification. The magistrate's awareness of the dangers of commodification is clear as he prefers barter and forbids payment in money: "in the past I have encouraged commerce but forbidden payment in money"(38).

When the Empire's agents come from the capitals, they bring with them cruelty and torture to those innocent barbarians. The magistrate not only opposes and resists their behaviors, but also comes to a deep questioning of the origin of this torture and dehumanization. After Mandel releases him from prison, the magistrate would not go without knowing how Mandel could eat after torturing people: "I would like to ask: how do you find it possible to eat afterwards, after you have been ... working with people? That is a question I have always asked myself about executioners and other such people" (126). The magistrate is so serious and sincere in his question that he insists in getting the answer:" Wait! 
Listen to me a moment longer, I am sincere, it has cost me a great deal to come out with this, since I am terrified of you, I need not tell you that, I am sure you are aware of it. Do you find it easy to take food afterwards?" (126). This deep and radical questioning of the psyche of those who committee such cruelty, is reflected deeply on the reader to make him dare not go through such ugly inhumane missions that "no ordinary washing would be enough" to make us able to eat again; it may require us a "priestly intervention, a ceremonial of cleansing" (126). But the question remains: what kind of ideologies has the ability to produce such cruel people? Another related ideology is materialism. In addition of educating its subjects against the 'other'-which is the barbarians in this case- the Empire makes them so dependant in materialism to think that their survival and success is tied to it. The first thing the magistrate notice when he first meets Colonel Joll is the glasses he wears. This material product is not only something new to the magistrate, but also makes a barrier between him and Colonel Joll because for him the eyes are the "only window of the soul": "I have never seen anything like it: two little discs of glasses suspended in front of his eyes in loops of wire"(1). Colonel Joll remarks that "at home everyone wears them"(1). In fact, these glasses, which are newly introduced to the magistrate that he considered them novelty, are reference to modernity. When people are consistently bombarded by this materialistic ideology without taking into consideration the human element, they will eventually be dehumanized; they will look at the human being, especially the 'other', as "a body, produced and reproduced in race, blood, and material inheritances — nose shape, cranial size, skin color"(Janet Thormann np). Thormann also referred to Giorgio Agamben's description of modern state apparatus as:

Exerting "bio power" under which the human person is reduced to a body, a body to be counted in censuses, to be constructed for industrial production and commodity consumption, to be studied and manipulated in medical practice, to be defined in reproduction (as, for example, when the murder of a pregnant woman counts as the murder of two)"(np).

She also referred to Étienne Balibar argument about the new concept of citizenship when he argues that this concept produced what he "designates as " the disposable human being"'(ibid). She also added that the "State inscription produces an other who is merely a natural body, only natural, outside the social symbolic". This view of the other, Balibar argues, produced what looks like, "at least in some cases, a 'natural' phenomenon, or a phenomenon of violence in which the boundaries between what is human and what is natural, or what is post-human and what is post-natural, tend to become blurred."(qtd. in Thormann).

Unlike this materialistic view of the human beings, the magistrate looks at the other from a human view. Out of respect, he calls the old prisoner "father"(Coetzee 3). He also prefers barter to the use of money in commerce. In fact, he is aware how the Empire turned its subjects into machines which perform its mission perfectly as the rules say without any regard for the human elements. Colonel Joll, for in- stance, follows the rules of modern psychology in torturing the prisoners and speaks like a mechanical instrument:

I am speaking only of a special situation now; I am speaking of a situation in which I am probing for the truth, in which I have to exert pressure to find it. First I get lies, you see - this is what happens - first lies, then pressure, then more lies, then more pressure, then the break, then more pressure, then the truth. That is how you get the truth (5).

In another situation, the magistrate describes Mandel in a way that reveals his mechanical programming that he becomes a machine devoid of the humanistic elements and care only for his physical appearance:

$\mathrm{He}$ is a good-looking man, with regular white teeth and lovely blue eyes. But vain I think. I picture him sitting up in bed beside a girl, flexing his muscles for her, feeding on her admiration. The kind of man who derives his body like a machine, I imagine, ignorant that it has its own rhythms (77).

It seems that the Empire prepared a catalogue which those agents follow without questioning; when Mandel accuses the magistrate of being "treasonously consorting" with the enemy, the magistrate describes the phrase-"treasonously consorting"- as "a phrase out of a book"(77). Those agents carry on what is in the catalogue without questioning its morality. The origin of these mechanical behaviors is the materialistic ideologies which the modern state-in our case it is the Coetzee's Empire-implants into its subjects mind. In his book Modernity and the Holocaust, Zygmunt Bauman argues that there is a connection between modern civilized society and genocide. He argues that modernity makes possible two parallel processes that enable genocide: "the division of labor" and the "substitution of technical for moral responsibility"(98). Bauman argues that in the modern corporation "technical responsibility differs from moral responsibility in that it forgets that the action is a means to something other than itself'(101). For Bauman, morality "boils down to the commandment to be a good, efficient and diligent expert and worker"'(102) above anything else. This leads to the "dehumanization of the objects of the bureaucratic operations" because it becomes possible "to express these objects in technical, ethically neutral terms"(102). The result of this "moral distancing" between the bureaucratic and the object of their interest, which is understood in "quantitative" terms is the "dehumanization" of the object of bureaucratic. "Reduced, like all other objects of bureaucratic management, to pure, quality-free measurements, human objects lose their distinctiveness"(103). Brian W. Shaffer argues that the barbarians or, as he calls them, "the victimized 'Others' [in the novel] are persecuted as a result of a dehumanization shift in the way they are represented and understood by those who define them"(12). The barbarians in the novel are defined by the Empire as being "barbarians" and dangerous. The Empire achieved this by spreading false rumors about them to make the people afraid of them:

The barbarians come out at night. Before the darkness falls the last goat must be brought in, the gate barred, a watch set in every lookout to call the hours. All night, it 
is said, the barbarians prowl about bent in murder and rapine. Children in their dreams see the shutters part and fierce barbarians faces leer through. "The barbarians are here!" the children scream, and cannot be comforted. Clothing disappears from washing-lines, food from larder, however tightly locked. The barbarians dug a tunnel under the walls, people say ... no body safe any longer. (134)

The Empire also bombarded its subjects with the false consciousness that they are serving a noble mission in fighting against the barbarians. This ideology helps in indoctrinating the torturers to identify the barbarians as being savages and criminals, while simultaneously cause them to feel self-satisfied the more they harm the barbarians and increase their dehumanization. As Bauman argues, the relationship between the double sides of such an ideology is that "dehumanization of the objects and positive moral self-evaluation [of the functionaries] reinforce each other. The functionaries may faithfully serve any goal while their moral conscience remains unimpaired". In stead of being morally and consciously affected, Mandel and Colonel Joll feels more self-evaluated when they persecute the barbarians.

After this deep self-questioning that leads the magistrate to the roots of this dehumanization of both the barbarians and the Empire agents, he also tries to reflect on the proper solutions to the problem. His main contemplation leads him to believe that the basis of our unity should be based on the fact that we are all human beings. Nationalism is not a valid basis of our unity. He tries his best to identify himself with the barbarians' suffering and to disassociate himself from the state which inflict violence on the barbarians. He begins this disassociation with the following self-questioning after his conversation with Colonel Joll where he discovers that, for the Empire, "pain is the truth; anything else is subject to doubt"(5): "On the other hand, who am I to assert my distance from him? I drink with him, I eat with him, I show him the sights, I offered him every assistance as his letter of commission requests, and more" (5-6). In fact, this self-investigation makes him reach a conclusion that the Empire adopts ideologies that lead not only to dehumanization, but also to fragmentation: "The Empire does not require that its servants love each other, merely that they perform their duty"(6). Knowing the truth about the Empire, the magistrate felt that it is his responsibility to react against it and not to be indifferent: "But it is the knowledge of how contingent my unease is, how dependant on a baby that wails beneath my window one day and does not the next, that brings the worst shame to me, the greatest indifference to annihilation"(21). This deep self-questioning and deep sympathy with the 'other' enable the reader to experience a similar sympathy, especially if they, like the magistrate, have knowledge about the reality of the Empire and the 'other'. He even describes himself to be "infected" with this knowledge and that "there seems to be no recovering"(21) from this knowledge except by resisting the false ideologies of the Empire. Before this knowledge, he could not even recall the blinded girl when she was in prison with her father; he tries his best to remem- ber where she was sitting but in vain while at that time he was indifferent to their suffering.

However, with the new knowledge, he got a new consciousness that change everything: "He takes in a young woman blinded by torture, consoles her, obsessively washes her body, tracing the lines of scars on her skin, trying to read her body but unable to penetrate her"'(Thormann np). He experiences a transition from a state where he could use her for his selfish desires into a situation where he make use of her situation for his own self-recovery from the cruelty of the modern Empire. Yet "He realizes that sympathy and consolation for the other is an insufficient ethical posture because it derives from superiority, from protection, from pain. His pity for the girl only distances her" (np.). The magistrate wants to tell us that we need a radical solution to the suffering of the 'other' by stopping the negative intervention of those who call themselves 'civilized' when they put themselves in a position to think for the other and plan their future. He wants to prove that any relationship which is built upon this assumption with the 'other' will certainly fail: "She said you were somewhere else. She could not understand you. She did not know what you wanted from her. You made her very unhappy"" (Coetzee 152). With this belief, the magistrate decides that the only solution is to send the girl back to her people. He cross the borders of the Empire and enter into the barbarians land, risking his life, just to say that he is against these borders which are based on colonization and opposition against the 'other'. He also decides to send her back to her people because he knows that being and feeling different in a state that gains its power from being inferior and different from the 'other', and where justice is limited for its citizens is really dangerous.

After he comes back, the magistrate finds his office occupied by the state officials: "the new barbarians usurping my desk and pawing my papers" (78). This makes him enter a new self-questioning stage: the physical torturing of the 'other'. He does not just question what exactly happens to the people who get tortured, but also question why his people enjoy watching those people being tortured without sympathizing with them. At this stage, the magistrate begins to describe what happen to oppressed people under torture. He was first reduced to "a pile of blood, bone and meat that is unhappy" (85). At the prison, he also gives a long description of what he feels after and during torture only to make the reader experience a real sympathy with the 'other'. He begins to "guzzle [his] food like a dog" and his life becomes "a bestial life" that turned him "into a beast"( 80$)$. Eventually, he will be turned into "a creature that believes in nothing"(81). He also encourages the reader to sympathize with anyone who is being tortured because that one could be the father or the sister of anyone of us. Experiencing torture, he begins to be more sympathetic with the barbarian girl and her father that he tried to put himself in their places: "all I can see is a figure named father that could be the figure of any father who knows a child is being beaten whom he cannot protect"(80). He also tried to put himself in the girl's place when she was tortured and see her father being tortured in front of her eyes: "Therefore 
she was no longer fully human, sister to all of us. Certain sympathies died, certain movements of the heart became no longer possible to her"(81). Thormann argues that "the capacity to feel pain, to be a body in pain, and to imagine an other in pain unites human subjects, as even death, unspeakable and really unimaginable, cannot"(np.). Without a real and deep sympathy with the barbarians, the magistrate would not be able to go deeply into their psychology to give us a clear idea of their feeling under torture. He wants us to be unified through sharing the pain because all the human beings have bodies that suffer from pain. He even criticizes why people enjoy watching other people like them being tortured without sympathizing with them. He escapes from prison just to save his people, especially children, from their "new and ravening appetite" (105) for watching bloodlust and enjoyment of cruelty. To convey this message to the audience, he protests against torturing the prisoners and shouts at Joll, who is about to hammer the naked "prisoners who lie docilely on the earth": "No" he cries repeatedly; "Not with that"... 'Look!' I shout. 'We are the great miracle of creation! But from some blows this miraculous body cannot repair itself! How-!' Words fail me. 'Look at these men!' I recommence. 'Men!'” (106-107). He uses the pronoun 'we' to remind Joll that he is torturing creatures exactly like him, and to show the audience that the prisoners are human beings like them.

The kind of justice and unity between the human beings which the magistrate imagines and reflects upon is justice and unity beyond the borders of land or based on legal citizenship. His attitude towards the barbarians who come near the Empire borders for barter and towards the fishermen who settle near the lake supports this argument. In her psychomedic review of the novel, Janet Thormann argues that "The problem of founding a political ethics, of determining a basis for justice for the subject of political community that is not limited by the status of citizenship, is the concern of J. M. Coetzee's novel, Waiting for the Barbarians"(np.). After figuring out the real ideology of the Empire, the magistrate wholly unifies himself with the barbarians on the basis of them being human beings, excluding any other considerations. The concept of citizenship is an excuse for many to exclude the other and dehumanize them because it reduces the number of people who will be accepted and protected by the Empire to those who share limited criteria like: " identification with race, tribe, or ethnicity and [being] speakers of a common language and believers in a common religion... being born in a territory and...inheriting a history"(np.). Thormann goes farther than that to say that:

Even while the rights of citizenship have been extended in western democracies-through, for example, the prohibitions of slavery, universal suffrage, naturalization of immigrants-new exclusions are defined. In the many of the United States, for example, ex-prisoners may not vote; illegal immigrants lack security and wage protection; temporary workers and foreign students live in a territorial limbo; refugees wait in holding zones and jails; the homeless camp on the streets. Throughout the world, those living in what are called "failed states" enjoy minimal rights, absent the state institutions that would enforce rights (np.).

This, as Janet thinks, means that "the identity of the citizen, like any identity, is predicated upon an other who may turns into a rival or enemy and becomes an object of violence"(np.). In fact, this argument is so related to the novel: the Empire wants to protect its citizens-who stand for white South Africans-by using violence to exclude the other human beings who are not white.

In conclusion, this paper shows that a deep analysis of the character of the magistrate shows that the mission of resisting colonization is not necessarily an exclusive mission that is carried on by colonized individuals, but rather a shared mission that even the colonizer can participate in it. Throughout the novel, the magistrate's confusion, introspection, and finally the remorse of his previous unintended participation in the process of dehumanization bring him and us, the readers, to a process of self-questioning and introspective awareness that resisted his participation in the process of dehumanization. As critical readers of Waiting for the Barbarians, we should gain the political sensibility that enables us to understand and analyze similar recurring situations, like the war in Iraq and the subsequent dehumanization of the prisoners of Abu Ghraib, Guantánamo, and other prisons in Iraq and Afghanistan. Moreover, this should lead us to the conclusion that we have to give the opportunity to our intellectuals to lead the world: psychoanalysts, sociologist, literary critics and other intellectuals could better lead the world to safety.

\section{REFERENCES}

Bauman, Zygmunt. Modernity and the Holocaust. NY: Cornell University Press, 1989.

Coetzee, J. M. Waiting for the Barbarians. New York: Penguin Books, 1982.

Eckstein, Barbara. "The Body, the Word, and the State: J. M. Coetzee's 'Waiting for the Barbarians"'NOVEL: A Forum in Fiction, Vol. 22, No. 2 (Winter, 1989), pp.175-198.

Moses, Michael Valdez. "The Mark of Empire: Writing, History, and Torture in Coetzee's Waiting for the Barbarians". The Kenyon Review, New Series, Vol. 15, No. 1 (Winter, 1993), pp. 115-127.

Shaffer, Brian w. Reading the Novel in English, 1950-2000. Malden, MA: Blackwell Pub., 2006.

Thormann, Janet. Rev. of Waiting for the Barbarian by J. M. Coetzee. Journal of European Psychoanalysis: Humanities, Philosophy, Psychotherapies. Feb. 2007. n.24. < http://www.psychomedia.it/jep/number25/coetzee.htm>.

Walder, Dennis. "History" Literary Theory: An Anthology. Ed. Julie Rivkin and Michael Ryan. Malden: Blackwell, 2004. 